\title{
The Function of the Spleen.
}

THE number of functions attributed to any organ is often a direct measure of our ignorance as to its real status in the animal economy. The spleen has suffered much from a multiplicity of theories as to its functions, but only two appear to be generally accepted; in fœtal life it acts as one of the sources of the cells of the blood, whilst in the adult these cells, especially the red cells, are here broken down and destroyed when they become worn out. It appears from recent work by Prof. J. Barcroft and his collaborators, an account of which is given in the Lancet of February I4, that a further extremely important function must be attributed to this organ; in their opinion it acts as a storehouse for the red cells of the blood, a number of which may be kept there ready to be brought back into the circulation at a time of emergency.

These workers were first led to a study of this question by finding that when the blood volume increases on exposure of the body to a high external temperature, the increase is not entirely due to the addition of fluid alone to the circulating blood, but that at the same time the total hæmoglobin circulating in the blood increases also. There is no evidence of an increase in the number of newly formed red cells until after a few days have elapsed, so that the additional hæmoglobin-and corpuscles containing it -must have come from some store, and not be due to a new formation, at any rate at first; moreover, the rate of appearance of this hæmoglobin is too great for it to be due simply to new formation. In their search for this store of red cells the investigators naturally thought of the spleen; if their supposition was to be considered correct, they must be able to answer in the affirmative these two questions: Is there, in fact, a store of red cells in the spleen, which are usually outside the general circulatory stream ? Is the number of these stored cells sufficient to account for the increase in circulating hæmoglobin observed on exposure to a high external temperature?

The answer to the first question was found by an examination of the effects of breathing small amounts of carbon monoxide upon the blood in the spleen. The experiments were conducted upon a number of different animals, and it was conclusively shown that there was a lag in the taking up of this gas by the red cells in the spleen as compared with those in the general circulation. In fact, if the percentage of gas breathed was sufficiently small, the hæmoglobin in the spleen might still contain none after several hours; on the other hand, when the animal was placed again in ordinary air, the carbon monoxide came off from the blood in the spleen much more slowly than from that in the general circulation. The blood in the spleen is thus outside the circulation, but this statement is only true for an animal at rest; in activity the carbon monoxide penetrates into the organ at once, so that under these conditions the stored blood appears to be in circulation. Further experiments have shown that under conditions where the amount of oxygen in the blood is less than normal, as, for example, after administration of carbon monoxide, the spleen is stimulated to contract by impulses from the central nervous system, the amount of blood forced out depending partly on the degree of such stimulation. Although it has been known for a long time that the spleen can undergo variations in size from the contraction of the unstriped muscle fibres it contains, the reason for this contractility is thus only now becoming apparent. Furthermore, bearing this capacity of the spleen to vary its size in mind, it may be asked: What is the real size of this organ? And are its variations in size of sufficient amplitude to account for the increase in circulating hæmoglobin with increase in the blood volume?

Little information on these questions can be derived from a study of the size of the spleen in the dead animal, since we have no means of knowing whether the muscle in it has maintained its in vivo length. We should expect to find, in fact, that it has contractèd, so that the organ will be smaller than in life; but how much smaller we cannot judge. It is clear that the organ must be examined in the living animal and without subjecting it to any exposure which might stimulate its smooth muscle fibres. Since it is not opaque to the X-rays, Barcroft and his co-workers fastened small metal clips to its edges in the living animal under an anæsthetic. After the wound had healed, X-ray photographs were taken in two planes, and from these it was easy to reconstruct in a model the size and shape of the organ under different conditions; the approximate weight was also ascertainable, after the animal had been killed, by comparing its size and weight after death with the size found during life. It was found that the weight during life might be two to six times that observed after death; in fact, no less than one-sixth of the total blood volume, or one-third of the red cells, might be contained in the organ during life. A comparison of its size at rest and during exercise suggests that an amount of blood equivalent to about one-quarter of the blood volume may be squeezed out of the organ during activity. The evidence appears conclusive that a large amount of blood may be stored in the spleen, available for emergencies.

Finally, since it is known that in man the spleen may be removed without apparent harm to the individual, Barcroft has inquired whether the absence or not of the organ makes any real difference to the organism. He found that animals without spleens died sooner than controls on exposure to an atmosphere containing carbon monoxide. Thus an individual with a spleen will be able to meet an emergency with more success than one from whom the organ has been removed.

\section{Science in Russia.}

$\mathrm{IT}^{\mathrm{T}}$ is gratifying to learn from a correspondent that, throughout the troubled period of the past few years, the splendid premises and wonderful collections of the famous Zoological Museum of the Academy of Sciences in Leningrad have scarcely felt the breath of war, famine, pestilence, and revolution which has passed over them. When the English traveller walks in, and is greeted by the famous young mammoth from Siberia, preserved like a recently killed specimen, and sees the rich collections illustrating the fauna of the vast steppes and deserts of Russian Asia, he feels that he is entering into a new world.

During the cold winter of I9I9-I920, when fuel was unobtainable, it was impossible to heat the Museum premises, but the staff suffered more than the collections. Little or no looting was done during the disorders, except that the director had some difficulty in preventing the valuable collection of skins from being taken to be used as furs by the shivering population. Far more damage was done 
during the severe floods last autumn, when the waters burst into the basement and ground floor, and at least one member of the staff actually saved his own life and that of others by swimming: the library was badly damaged, many valuable specimens were ruined by the water and damp, and great inconvenience was caused by the smashing of the stores of alcohol, which is difficult to obtain to-day in Russia, as the supply is under strict Government control and very limited.

The entomological collections were enriched in I9I4 by the generous gift by A. P. Semenov-TianShansky of an immense collection of Central Asiatic Coleoptera, consisting of no less than 800,000 specimens: the same donor last year presented his own collection of Hymenoptera, Diptera, Neuroptera.

The staff of the Zoological Museum consists of ten "senior zoologists," who form a " soviet" and elect their own director, ten " keepers," and eight assistants. The present director is A. A. Bialitsky-Birula, well known from his work upon Arctic zoology, who is also editor of the Annuaive. Birds are under the charge of P. P. Sushkin, Member of the Academy, who is well known in Great Britain and the United States. Another name well known outside his own country is that of the entomologist A. P. Semenov-TianShansky, whose many friends will regret the sad news of his failing eyesight. Fortunately, his general health leaves nothing to be desired, and it is to be hoped that he will be spared with capacity for useful work for many years. His father, P. P. Semenov, was a distinguished explorer, who surveyed the Tian Shan mountains, receiving the authority of the Tsar to add the title Tian-Shansky to his surname. Other well-known members of the staff are N. J. Kuznetsov the lepidopterist, G. G. Jacobson the coleopterist, A. K. Mordviko the aphidologist, P. I. Schmidt the ichthyologist, A. N. Kirichenko and A. M. Diakonov, entomologists.

The staff of the Museum are, of course, State officials, and paid at least a living wage: the salary of a senior zoologist is 47 gold roubles a month, equivalent to about $5 l$.: this, of course, leaves no margin for luxuries, but they are at least happy in their devotion to science. Their chief complaint has been the shortage of modern foreign literature, but this is now to a certain extent being made good. There is, however, considerable leeway to make up, and as the postal arrangements are now working satisfactorily, zoologists in England will be doing good work if they bear this in mind.

During recent years it has not been possible to publish the results of research work in agriculture in Russia, since the scanty funds for agricultural publications have been used, in the first place, for publishing popular handbooks and pamphlets. At the same time, research work has been carried on, often under most unfavourable conditions, and a considerable amount of new facts is awaiting publication. The new journal (Journal für landwirtschaftliche Wissenschaft, vol. i. Nos. I-6; Moscow, 1924 (in Russian)), edited by a group of leading professors and research workers of the Moscow Agricultural Academy, aims at becoming a medium for publishing results of research work in all branches of agricultural science. The five numbers (one double) before us now include a great variety of papers on different subjects.

One of the most interesting papers is by A. G. Dojarenko, on the utilisation of solar energy by plants (No. I, pp. 7-2I), which describes the methods used in the author's experimental work for exact measurements of solar energy both received and utilised by cultivated plants, and gives interesting, though only preliminary, conclusions. Of considerable general interest is a paper by A. R. Minenkov (No. I, pp. 29-47) dealing with the problem of chemical determination of sex in plants and in animals; the results of his experimental work are that both in plants and in animals there is a definite sexual difference in the fermenting properties of extract (plants) or blood (animals) which enables one to determine the sex. A. D. Prianishnikov (No. 3, pp. I79-I 90) describes experiments on the transformation of nitrogen compounds in plants and in animals, the author's conclusion being that the analogies in this respect are very far-reaching and suggest a close similarity of processes in plants and in animals. In a paper by V. Israilsky and E. W. Runov the question of the action of vitamins on bacteria is discussed and experiments described, which tend to show that bacteria are very sensitive to vitamins. G. D. Karpetchenko (No. 5-6, pp. 390-4 Io) describes hybrids between two plants of different genera, Raphanus satinus L. and Brassica oleracea L.; an exhaustive study of the morphology and cytology of hybrids is given. These are only a few of the more interesting papers from the journal, which represents, on the whole, an important step in the development of agricultural science in Russia. The value of the journal to Russian agricultural research workers is greatly enhanced by abstracts of current literature.

\section{University and Educational Intelligence.}

Birmingham.--The Council of the University at its meeting on March 4 decided to go forward with its purpose for erecting further buildings at Edgbaston to accommodate the three biological departments, botany, zoology, and brewing, with the fermentation industries. The approximate estimate of expenditure is $90,000 l .-100,000 l$., and the scheme is only rendered possible by a very generous donation from $\mathrm{Mr}$. W. Waters Butler of $35,000 l$. Another donation to the fund of $5000 \mathrm{l}$, given anonymously, was also reported. The Biological Departments are at present quite inadequately housed in Edmund Street, and the release of the space in the Edmund Street buildings will enable rearrangements to be made there to facilitate the work of the Faculties of Arts and Medicine, and the new Department of Law. When the University was founded in I90o, an imposing scheme for the site at Edgbaston was planned by Sir Aston Webb. Substantial progress had been made when the present buildings were opened by King Edward in I909. The War and its economic consequences, however, prevented further progress. The new biological block is a resumption, long delayed, of the original plans.

CAMBRIDGE.- It is proposed to confer Honorary Degrees upon Prof. John Joly, professor of geology and mineralogy in the University of Dublin, and on Mr. A. P. Maudslay.

The Board of Archæological and Anthropological Studies is recommending certain changes in the regulations for the diploma in anthropology. One change would throw open the diploma to any officer of one of the public services of the Empite, not ordinarily resident in the British Isles, who has resided and received instruction in anthropology in Cambridge during three terms or, in the case of an officer possessed of exceptional qualifications, during one term only.

LEEDS.-The degree of Doctor of Science has been awarded to Mr. H. Hunter for his thesis on "The Improvement of the Barley Crop "; and the degree NO. 2889 , VOL. I I 5$]$ 